\title{
Lawful physician-hastened death
}

\section{AAN position statement}

James A. Russell, DO, Leon G. Epstein, MD, Richard J. Bonnie, LLB, Robin Conwit, MD, William D. Graf, MD, Matthew Kirschen, MD, PhD, Julie A. Kurek, MD, Daniel G. Larriviere, MD, JD, Robert M. Pascuzzi, MD, Matthew Rizzo, MD, Justin A. Sattin, MD, Zachary Simmons, MD, Lynne Taylor, MD, Amy Tsou, MD, and Michael A. Williams, MD On behalf of the Ethics, Law, and Humanities Committee (a joint committee of the AAN, ANA, and CNS)

Neurology ${ }^{\circledR}$ 2018;90:420-422. doi:10.1212/WNL.0000000000005012

In 1998, the American Academy of Neurology published its prior position on physicianhastened death, titled "Assisted suicide, euthanasia, and the neurologist." In that statement, the American Academy of Neurology (AAN) expressed its vigorous opposition to its members' participation in either physician-assisted suicide (PAS) (prescription without clinician administration) or euthanasia (prescription with clinician administration). ${ }^{1}$ At that time, physician participation in either of these hastened-death practices was illegal in all US jurisdictions except Oregon.

In 1994, Oregon became the first US jurisdiction to enact legislation legalizing PAS, although litigation prevented the law from going into effect until October 1997. ${ }^{2}$ Since then, PAS, when requested by terminally ill adults and practiced within regulated boundaries, has become legal in 6 states (California, Colorado, Oregon, Montana, Vermont, and Washington) and in the District of Columbia. ${ }^{2}$ One in 5 US citizens and the neurologists who care for them now have lawful access to PAS. ${ }^{3}$ This legal trend appears to parallel increasing public support for lawful physician-hastened death (LPHD), which approximates $70 \%$ of 1,000 surveyed individuals in one poll. ${ }^{4}$

AAN members are ethically guided by its Code of Professional Conduct (CPC). This document, although not specifically addressing hastened-death practices, directs its members to "relieve the suffering" and to "respect the wishes" of dying patients. ${ }^{5}$ As a consequence of evolving law, the prior AAN position on PAS, and CPC guidance, AAN members practicing in PAS-lawful jurisdictions may feel conflicted when their dying patients request assistance in hastened death. In consideration of this, the Ethics, Law and Humanities Committee (a joint committee of the AAN, the American Neurological Association, and the Child Neurology Society), after 2 years of deliberation, unanimously recommended to the Boards of the AAN and the AAN Institute that the 1998 position be retired. The Ethics, Law and Humanities Committee undertook this difficult consideration while respectfully acknowledging that there remain cogent opinions from those who both endorse and oppose LPHD practices. On December 1, 2016, the AAN and the AAN Institute unanimously endorsed this recommendation. The Child Neurology Society has subsequently endorsed this position whereas the American Neurological Association has chosen to recuse itself from rendering a decision. The following briefly summarizes the basis for the Ethics, Law and Humanities Committee recommendations to the AAN and AAN Institute Boards.

\section{Correspondence}

Dr. Russell

james.a.russell@lahey.org

From the Department of Neurology (J.A.R.), Lahey Hospital and Medical Center, Burlington, MA; Neurology Division (L.G.E.), Ann \& Robert H Lurie Children's Hospital of Chicago, IL; Harrison Foundation Prof. of Law and Medicine (R.J.B.), University of Virginia School of Law, Charlottesville; Neurosciences Center (R.C.), National Institutes of Health, Bethesda, MA; Department of Neurology (W.D.G.), Connecticut Children's Medical Center, Hartford; Department of Neurology (M.K.), The Children's Hospital of Philadelphia, PA; Department of Neurology (J.A.K.), Augusta University at the Medical College of Georgia; Department of Neurology, (D.G.L.), Ochsner Medical Center, Jefferson, LA; Department of Neurology (R.M.P.), Indiana University School of Medicine, Indianapolis; Department of Neurology (M.R.), University of Nebraska Medical Center, Omaha; Department of Neurology (J.A.S.), University of Wisconsin School of Medicine and Public Health, Madison; Department of Neurology (Z.S.), Penn State Hershey Medical Center; Alvord Brain Tumor Center (L.T.) and Department of Neurology (M.A.W.), University of Washington Medical Center, Seattle; and Emergency Care Research Institute (A.T.), Philadelphia, PA.

Coinvestigators are listed at http://links.Iww.com/WNL/A225.

Go to Neurology.org/N for full disclosures. Funding information and disclosures deemed relevant by the authors, if any, are provided at the end of the article.

The American Academy of Neurology is retiring its 1998 Position Statement titled "Assisted suicide, euthanasia, and the neurologist." 


\section{Glossary}

AAN = American Academy of Neurology; CPC = Code of Professional Conduct; LPHD = lawful physician-hastened death; PAS $=$ physician-assisted suicide.

The Ethics, Law and Humanities Committee was influenced by the results of a 2014 AAN-sponsored Ethics, Law and Humanities Committee survey that suggested that a notable percentage of AAN members might feel bound by conscience to comply with the wishes of their dying patients for assistance in hastening death (appendix e-1, http://links. lww.com/WNL/A270). In this survey, more than $70 \%$ of responding members in PAS-lawful states endorsed LPHD as an ethically permissible behavior, and more than $50 \%$ of these same individuals reported that they would be willing to assist their patients in lawful hastened death. The Ethics, Law and Humanities Committee also recognized that the AAN vision (to be indispensable to its members) was potentially jeopardized by conflicting guidance provided by changing PAS laws, the AAN CPC, and the existing 1998 Position Statement.

In their recommendation, the Ethics, Law and Humanities Committee purposely chose to adopt the term LPHD (synonymous with PAS in the United States). The committee chose LPHD in lieu of PAS to remove any ambiguity regarding patient motivation, which is not to commit suicide per se, but to hasten death in order to relieve suffering. The committee avoided terms such as assisted death or dying, which if misinterpreted in a literal sense could be erroneously construed to include the beneficial assistance in the dying process provided by palliative care.

The Ethics, Law and Humanities Committee approached the ethical analysis of LPHD from 2 perspectives-the boundaries of individual physicians' fiduciary responsibility to their patients and the effect of hastened death practice on societal trust of the medical profession as a whole. In consideration of the moral boundaries of an individual physician's care of a dying patient, the committee considers LPHD to be morally distinctive from other medical interventions that do or may hasten death such as the withdrawal of life-sustaining treatments, palliative sedation, and euthanasia. Unlike these interventions, both the request for and administration of the intervention in LPHD when regulated remain under the control of the patient. The Ethics, Law and Humanities Committee endorses the belief that the primary role of a physician is to prevent and treat disease whenever possible. At the same time, the committee strongly endorses the provision of palliative care to alleviate suffering in patients with illnesses that are unresponsive to disease-specific treatments. In addition, it expresses support for improved availability of palliative care services, palliative care education for AAN members, and palliative care research intended to identify more effective means to alleviate refractory suffering of dying patients. By doing so, it hopes to minimize future patient interest in hastened death. However, the committee recognizes that palliative care interventions may not be universally effective for all terminally ill patients who may seek hastened death assistance from AAN members, particularly with spiritual or existential suffering. ${ }^{6}$

The Ethics, Law and Humanities Committee also considered the potential effect of any change in the AAN position on the public trust of the medical profession and AAN members in particular. Relevant to this concern, it reviewed the 18-year experience of LPHD in Oregon and the opinions of those who have critiqued it. ${ }^{7,8}$ The committee recognizes that many but not all who have reviewed and written on this experience have been reassured by the safeguards provided. This reassurance arises in part from the knowledge that only 2-thirds of individuals ingest the prescription they receive. ${ }^{2}$ More importantly, reassurance stems from the safeguards provided by regulations that require a terminally ill adult resident of Oregon with capacity for decision-making and capability of selfadministration to request assistance from a physician twice in an interval of 15 days supplemented by a written request cosigned by 2 witnesses. In addition, the patient must be apprised of alternatives to PAS and undergo psychiatric assessment if in the judgment of either the prescribing physician or the required consulting physician the patient's judgment is psychologically impaired. Failure to follow these regulations is illegal and reportable. While reassuring, the committee acknowledges that hastened death practices should be continually monitored as they remain potentially susceptible to erosion over time..$^{8-10}$

In consideration of the Ethics, Law and Humanities Committee recommendations, the AAN Board of Directors carefully deliberated this important issue, taking into account the evolving legal environment, all aspects of the ethical debate, the reported values of AAN members, and expectations of their adult patients dying of neurologic illness. Accordingly, the AAN has decided to retire its 1998 position on "Assisted suicide, euthanasia, and the neurologist" and to leave the decision of whether to practice or not to practice LPHD to the conscientious judgment of its members acting on behalf of their patients. The Ethics, Law and Humanities Committee and the AAN make no attempt to influence an individual member's conscience in consideration of participation or nonparticipation in LPHD. Although the AAN endorses the belief that LPHD decisionmaking is ideally made within a well-established patient/ 
doctor relationship, it places no obligation on its members to identify another physician willing to participate should their conscience preclude them from participation. The AAN remains opposed to member participation in euthanasia, which remains illegal in all US jurisdictions, regardless of its legal status in the jurisdiction in which an AAN member may practice.

\section{Author contributions}

James A. Russell, DO, FAAN: principal author of position statement and all subsequent revisions. All other authors: reviewed relevant literature, active involvement in multiple committee meetings in which document content was deliberated, active involvement in editing multiple iterations of document.

\section{Acknowledgment}

The authors thank John Hutchins, Karen Kasmirski, Bruce Levi, and Sarah Nelson for guidance in crafting this position.

\section{Study funding}

No targeted funding reported.

\section{Disclosure}

No relevant disclosures are reported. Go to Neurology.org/N for full disclosures.

Received January 13, 2017. Accepted in final form December 8, 2017.

\section{References}

1. Pellegrino T, Bereford R, Bernat JL, et al; for The Ethics, Law and Humanities Committee of the AAN. Position statement: assisted-suicide, euthanasia and the neurologist. Neurology 1998;50:596-598.

2. Death With Dignity Act [online]. Available at: oregon.gov/oha/ph/ProviderPartnerResources/EvaluationResearch/DeathwithDignityAct/Pages/ors.aspx. Accessed March 2016.

3. Bernat JL, McQuillen MP. Physician-assisted death in chronic neurologic diseases. Neurology 2017;88:1488-1489.

4. Dugan A. In U.S., support up for doctor-assisted suicide [online]. Available at: http:// news.gallup.com/poll/183425/support-doctor-assisted-suicide.aspx. Accessed March 2016.

5. The American Academy of Neurology Code of Professional Conduct. Neurology 1993;43:1257-1260.

6. Ganzini L, Nelson HD, Schmidt TA, Kraemer DF, Delorit MA, Lee MA. Physician's experiences with the Oregon Death with Dignity Act. N Engl J Med 2000;342:557-563.

7. About the Death With Dignity Act [online]. Available at: http://www.oregon.gov/ oha/PH/PROVIDERPARTNERRESOURCES/EVALUATIONRESEARCH/ DEATHWITHDIGNITYACT/Pages/faqs.aspx. Accessed January 2018.

8. Hendin H, Foley K. Physician assisted suicide in Oregon: a medical prospective. Mich L Rev 2008;106:1613-1638.

9. Lindsay RA. Oregon's experience: evaluating the record. Am J Bioeth 2009;9:19-27.

10. Emanuel EJ, Onwuteaka-Philepsen D, Urwin JW, Cohen J. Attitudes and practices of euthanasia and physician-assisted suicide in the United States, Canada, and Europe. JAMA 2016;316:79-90.

\section{Neurology in the Spotlight at 2018 Annual Meeting in Los Angeles}

Registration is now open for the totally flexible, dynamic 2018 Annual Meeting. We'll be shining the spotlight on neurology and what you need to excel in your career. Look for the latest science, education, and networking you won't find anywhere else when the biggest names in neurology and neuroscience convene in Los Angeles April 21 through 27. Learn more and register now at AAN.com/view/AM18.

\section{Neurology ${ }^{\circledR}$ Online CME Program}

Earn CME while reading Neurology. This program is available only to online Neurology subscribers. Read the articles marked CME, go to Neurology.org, and click on CME. This will provide all of the information necessary to get started. The American Academy of Neurology (AAN) is accredited by the Accreditation Council for Continuing Medical Education (ACCME) to sponsor continuing medical education for physicians. Neurology is planned and produced in accordance with the ACCME Essentials. For more information, contact AAN Member Services at 800-879-1960. 


\title{
Neurology
}

\author{
Lawful physician-hastened death: AAN position statement \\ James A. Russell, Leon G. Epstein, Richard J. Bonnie, et al. \\ Neurology 2018;90;420-422 \\ DOI 10.1212/WNL.0000000000005012
}

This information is current as of February 26, 2018

\section{Updated Information \& Services \\ References \\ Citations \\ Subspecialty Collections}

Permissions \& Licensing

Reprints including high resolution figures, can be found at: http://n.neurology.org/content/90/9/420.full

This article cites 7 articles, 3 of which you can access for free at: http://n.neurology.org/content/90/9/420.full\#ref-list-1

This article has been cited by 5 HighWire-hosted articles: http://n.neurology.org/content/90/9/420.full\#\#otherarticles

This article, along with others on similar topics, appears in the following collection(s):

\section{All Ethics in Neurology/Legal issues}

http://n.neurology.org/cgi/collection/all_ethics_in_neurology_legal_iss ues

Legislative affairs

http://n.neurology.org/cgi/collection/legislative_affairs

Palliative care

http://n.neurology.org/cgi/collection/palliative_care

Professional conduct and ethics

http://n.neurology.org/cgi/collection/professional_conduct_and_ethics

Information about reproducing this article in parts (figures,tables) or in its entirety can be found online at:

http://www.neurology.org/about/about_the_journal\#permissions

Information about ordering reprints can be found online:

http://n.neurology.org/subscribers/advertise

Neurology ${ }^{\circledR}$ is the official journal of the American Academy of Neurology. Published continuously since 1951, it is now a weekly with 48 issues per year. Copyright (O) 2018 American Academy of Neurology. All rights reserved. Print ISSN: 0028-3878. Online ISSN: 1526-632X.

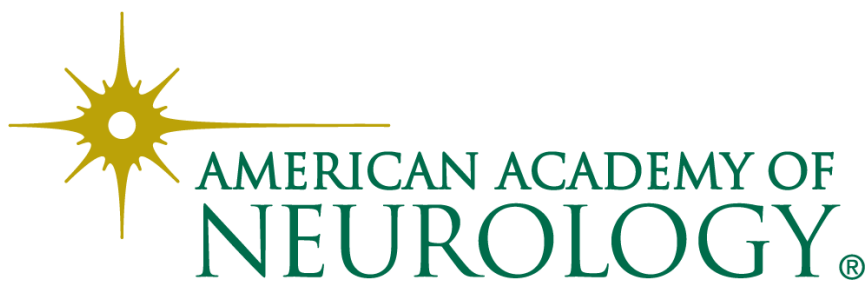

